Journal of Economics and Behavioral Studies

Vol. 6, No. 9, pp. 760-770, September 2014 (ISSN: 2220-6140)

\title{
Efficiency of Capital-Labor in Nigeria's Mining Sector: A Cobb-Douglas Framework
}

\author{
*Kanayo Ogujiuba ${ }^{1}$, Francis Adebayo ${ }^{3}$, Nancy Stiegler ${ }^{2}$ \\ ${ }^{1}$ Research Division National Institute for Legislative Studies, Abuja, Nigeria \\ 2University of Western Cape - South Africa \\ ${ }^{3}$ Ken Nnamani Centre for Leadership and Development, Abuja - Nigeria \\ *kannyog@gmail.com
}

\begin{abstract}
The productivity in the Nigeria's mining sector presents significance challenges, especially in view of its prospect in diversifying the national economy. The need to uncover the efficiency by way of estimating two major production functions (i.e. capital and labor) cannot be minimized. However, this paper uses econometric technique to estimates the Cobb-Douglas production function of mining sector between 1980 and 2011 periods in Nigeria. To avoid a spurious series, unit root test was conducted based on Augmented Dickey-Fuller (ADF) to test for the stationarity or otherwise of the variables in the model. The outcome reveals that the substitution parameters $\alpha$ and $\beta$ (substitution parameters for capital and labor) confirms the a priori expectation that the pair of $\alpha$ and $\beta$ are positive values. Despite labor is the most significant factor of production, the study also found that other inputs such as innovations and technology are positively significant in this period of modern mining production processes in view of the global economic outlook. The study amongst others recommends strong political will of government, transparency and accountability to drive efficient and effective mining sector reform, increased capital investment in innovations, technology, and raw materials.
\end{abstract}

Keyword: Productivity, Production Function, Cobb-Douglas

\section{Introduction}

The mining sector is a key driver of economic growth and development process (Bradshaw, 2005), and as lead sector that drive economic expansion which can lead to higher levels of social and economic security (Bridge, 2008). Many countries such as Australia, Botswana, Canada, India, Russia, and Saudi Arabia depend on their mineral wealth to finance their societies. Australia benefitted from mineral export, earning up to AUD 59.2 billion in 2006 alone (ICMM, et al., 2007), and Canada's estimated mineral production in 2010 was $\$ 41.3$ billion. ${ }^{1}$ In Botswana, Mineral exports of which diamond accounted for $\$ 3.3$ billion; copper and nickel matte, about $\$ 461$ million; soda ash, about $\$ 65$ million; and gold, about $\$ 36$ million, represented $83 \%$ of total merchandise exports. ${ }^{2}$ Before the discovery of oil in the 1950 s, solid minerals played a central role in the economic development of Nigeria. Indeed, the export of solid minerals was once a major foreign exchange earner. Having become monopolized by state-owned corporations, the industry became privatized in the early 2000s. As a result of the immense concentration on the oil and gas industries by domestic and multinational companies, the mining of solid minerals in Nigeria remains underdeveloped and thus contains much potential. Various reports suggest that Nigeria may have the largest coal deposits in Africa. ${ }^{3}$ The highest contribution of the mining category was in 1975 with a share of $31.6 \%$ declining steadily to $28.8 \%$ and then to $16.5 \%$ in 1980 and 1985 respectively (CBN, various years). Other sectors in the mining sector contributed decreasing shares of GDP during the same period: oil sector contribution was $30.15 \%$ in 1975 and only $16.07 \%$ in 1974 . Coal and metal ore contributions decreased from $0.01 \%$ and $1.73 \%$ in 1974 respectively to $0.0 \%$ and $1.32 \%$ in 1975 respectively. 4

\footnotetext{
${ }^{1}$ See http://www.nrcan.gc.ca/statistics-facts/minerals/902

${ }^{2}$ See http://en.wikipedia.org/wiki/Mining_industry_of_Botswana

${ }^{3}$ See http://www.commonwealthofnations.org/sectors-nigeria/business/mining_and_minerals/

${ }^{4}$ See Hello International, 2009 in http://www.helio international.org/VARNigeria.En.pdf
} 
The performance of mining and quarrying sector has not been consistent between 1980 and 1995. At current factor prices, the mining sector which contributed about $\mathrm{N} 1$ billion to the GDP in 1980 had grown to contribute $\mathrm{N} 0.8$ billion in 1985 . It declined to $\mathrm{N} 0.6$ billion in 1990 and increased sharply to $\mathrm{N} 2.7$ billion in 1995. That Nigeria is highly endowed with a large volume of solid minerals is no news. However, the sector has not made significant contribution to the nation's Gross Domestic Product owing to a variety of factors. ${ }^{5}$ The sector continued to increase its contribution to GDP between 1996 and 2011 with N2.3, N2.4 3.7, $\mathrm{N} 4.1, \mathrm{~N} 4.8, \mathrm{~N} 5.9, \mathrm{~N} 7.7, \mathrm{~N} 8.3, \mathrm{~N} 11.7, \mathrm{~N} 17.3, \mathrm{~N} 27.3, \mathrm{~N} 31.5, \mathrm{~N} 36.2, \mathrm{~N} 40.6, \mathrm{~N} 45.7$, and $\mathrm{N} 52.4$ billion, respectively (CBN, 2012). Minerals resource should be a catalyst for development however, this sector has not performed well economically over the last several decades (see Table 1). Analysts have suggested that Nigerian economy would be better off leaving the mineral resources in the ground. Others, however, argued that there is nothing inevitable about poor economic performance in the mineral economies; poor performance, it is argued, is due to other (non-mineral) factors (Eggert, 2001). This situation has led to growing competition between nations to capture investments and, consequently, minerals policy, legal frameworks and institutions were reformed to encourage foreign and local investments in the extractive sector, and to optimize the contribution of mining to the national economy. For example, Madagascar, Ghana, Tanzania, Peru, Argentina and Chile have achieved remarkable success in this regard (Gironeset al., 2009).

With the return to democracy in 1999 , the need to diversify the revenue base of the country became paramount. A new national focus and strategy on mining evolved such that in 2007, the Nigerian Minerals and Mining Act (the Act) was enacted to revitalize the Nigerian mining industry. ${ }^{6}$ Nigeria's mineral development has been highly focused on its oil industry. Nigeria is Africa's largest oil producer and contributes $3 \%$ to global production. Nonetheless, mining sector in the Nigerian context includes all minerals and metals, excluding oil and gas. As a result, the mining industry has been neglected and has only been revived by the Ministry of Solid Mineral Development, intent in increasing the role of this sector of Nigeria's economy. Currently, mining contributes less than $1 \%$ to Nigeria's GDP (2011 est.) ${ }^{7}$ and has the potentials to contribute more with significant coal and iron ore reserves as well several gold, uranium, and tantalum showings throughout the country. ${ }^{8}$ The mining sector is a sector that has been neglected since after the 1980s probably because of the discovery and extraction of crude oil in commercial quantity which has been considered a 'hot cake' in the international market. Thus, resources have been channeled into this sector at the expense of mining sectors among others.

\section{Table 1: Growth in Nigeria's Mining Sector}

\begin{tabular}{lll}
\hline Year & $\begin{array}{l}\text { \% share of mining in } \\
\text { GDP }\end{array}$ & Growth rate of mining \\
\hline 1980 & 1.06 & - \\
1985 & 0.45 & -57.5 \\
1990 & 0.24 & -46.7 \\
1995 & 0.28 & 16.7 \\
2000 & 0.29 & 3.6 \\
2005 & 0.12 & -58.6 \\
2006 & 0.15 & 25 \\
2007 & 0.15 & 0 \\
2008 & 0.15 & 0 \\
2009 & 0.16 & 6.7 \\
2010 & 0.1 & -37.5 \\
2011 & 0.1 & 0 \\
\hline
\end{tabular}

Source: CBN Statistical Bulletin, (2004, 2009 and 2011).

\footnotetext{
${ }^{5}$ See more at: http://www.vanguardngr.com/2013/06/32-billion-japanese-grant-nigerian-mining-sector-can-benefitekosin/\#sthash.PIkkBDMG.dpuf.

${ }^{6}$ See the Nigeria mining sector by KPMG, February, 2012.

${ }^{7}$ See CBN 2011 Statistical Bulletin

${ }^{8}$ see overview of the mining sector by FO Akinrele\& Co
} 
Selected indicators of the mining sector in Nigeria between 1980 and 2005 indicated that in 1980, the share of mining in Nigeria's GDP was $1.06 \%$ declined sharply to $0.45 \%$ in 1985 and further declined to $0.24 \%$ in 1990. This however, increased to $0.28 \%$ in 1995 and slightly to $0.29 \%$ in 2000 . In 2005, it declined drastically to $0.12 \%$. Consequently, it increased to $0.15 \%$ between 2006 and 2008 , respectively. It increase slightly to $0.16 \%$ in 2009 and began to decline to $0.1 \%$ in 2010 and 2011 periods. The implication of this analysis suggests lack of government political will to address its numerous challenges such as informal/illegal mining activities which have been on the increase in recent time. The activities of these informal/illegal miners have impaired the performance of this sector to GDP.

The reason for the low contribution of mining sector to GDP is that Nigerian economy is mainly dependent on oil; non-oil minerals have relatively weak roles. Though, the current global economic recession, especially oil price volatility in the international market has induced the government of Nigeria to reduce the risk of overdependence on oil by giving significant attention to solid mineral development. Nigerian mining has remarkable prospective for economic development (Gyang et al., 2010). Davenport (2010) stated that the expansion of mining has the potential to contribute 15\% to Nigeria's GDP by the year 2015 from the present less than $1 \%$ contribution. Hitherto, various policies have been formulated to regenerate the declining sector for economic diversification and increased revenue. One of the key components of the mining reform was establishing a modern cadastre system that grants mining permits and licences (Chindo, 2011). Examining the growth dynamics in Nigeria's mining sector is an attempt at the estimation of production function. This paper seeks to estimate the Cobb-Douglas production function of mining sector between 1980 and 2011 periods in Nigeria. Against this backdrop, the paper is divided into five sections. The first section presents the introduction comprising the background and contribution of the sector to the economy. The second section focuses on a brief review of literature and empirical review of the factors explaining productivity and growth performance. The third section presents the theoretical framework. The fourth section examines the methodology and analysis of the data. The fifth section presents the conclusion and policy options of the study.

Historical Trends: Mining in Nigeria is over 2,400 years old with early mining taking place in the form of artisanal mining as practiced by communities while searching for natural resources within their environment for their social and economic gains. This was the case with the ancient civilizations as seen in the Nok Culture (340 BC), the Igbo Ukwu bronze civilization (705 AD) Ife and Benin Bronze works flourished between 1163$1200 \mathrm{AD}$ and 1630-1648 AD, respectively, using basic clays, base metals and gold amongst others. ${ }^{9}$ Organized mining began in 1903 when the Mineral Survey of the Northern Protectorates was created by the British colonial government. A year later, the Mineral Survey of the Southern Protectorates was founded. By the 1940s, Nigeria was a major producer of tin, columbite, and coal. The discovery of oil in 1956 hurt the mineral extraction industries, as government and industry both began to focus on this new resource. Furthermore, the Nigerian Civil War in the late 1960s led many expatriate mining experts to leave the country. ${ }^{10}$

Bitumen was first discovered in 1900, and exploration began in 1905. Bitumen deposits are found in Lagos State, Ogun State, Ondo State, and Edo State. Nigeria has several deposits of iron ore, but the purest deposits are found around Itakpe in Kogi State. ${ }^{11}$ Coal was first discovered in Enugu in 1909, and the Ogbete Mine had begun extracting coal by 1916. By 1920, coal production had reached 180,122 long tons (183,012 t). In 1950, the Nigerian Coal Corporation (NCC) was formed and held a monopoly on the mining, processing, and sales of coal, lignite, and coke products until 1999. Nigeria's peak coal production was in the late 1950s, and by 1960 production was at 565,681 long tons $(574,758 \mathrm{t})$. After the war ended in the early 1970 s, coal production was

\footnotetext{
${ }^{9}$ See Federal Republic of Nigeria Nigeria Extractive Industries Transparency Initiative (NEITI) Prepared by Geological Survey of Denmark and Greenland, GEUS (DK) in association with Bureau of Minerals and Petroleum (Greenland) Minre Associates (NG)Meyetty Nigeria Limited (NG)

${ }^{10}$ seehttps://en.wikipedia.org/wiki/Mining_industry_of_Nigeria.

${ }^{11}$ See http://www.onlinenigeria.com/minerals/?blurb=517 retrieved 29/07/13
} 
never able to recover. Attempts to mechanize the industry in the 1970 s and 1980s were ultimately unsuccessful, and actually hindered production due to problems with implementation and maintenance. ${ }^{12}$

Nonetheless, Gold production began in 1913 and peaked in the 1930s. During the Second World War, production declined. Columbite and Tantalite are ores used to produce the elements niobium and tantalum. They are collectively known as coltan in Africa. Tantalum is a valuable rare element used in electronics manufacturing. These pegmatites are found in Nassarawa State near the Jos Plateau, as well as in several areas in southeast Nigeria. There is small-scale mining of these minerals. Recently, several important uranium deposits were discovered in Cross River State, Adamawa State, Taraba State, Plateau State, Bauchi State, and Kano State by the British Geological Survey. ${ }^{13}$ Tin, lead and zinc among others non-ferrous metals are mined in Nigeria. For example, tin has been mined since the colonial times and is one of the most versatile metals commonly used in industry. Tin ore (cassiterite or tinstone) is obtained mostly from the younger granites in the northern parts of the country and has been largely won from old stream channel deposits (placers) on the Jos Plateau and around younger granite masses in Bauchi, Kaduna, Kano and Benue States. Also, pegmatite discovered in Cross River, Oyo, Niger, Kwara and Plateau States had also supplied tin in the past.

\section{Literature Review}

The studies of Douglas (1934) and Solow (1957) on capital-labor substitution concluded that labor is the single most important factor of production in a certain subtle sense. Both labor and capital are needed in production. Take away capital, or alternatively all labor, and you will be left with negligible total product. They found that a one percent increase in labor seems to increase output about three times as much as would a one percent increase in capital. This largely corresponds with the widely known fact that wages are about three fourth of the share of property incomes. Krueger \& Turner (1982) provides an extensive overview of coal mining in Canada, and the role of labor-management relations in Canadian coal production. The study makes some observations on the drivers of productivity in coal mining, including an early recognition of the importance of research and development in improving recovery rates and average production per shift. Factors mentioned as contributing negatively to the productivity performance of coal mining in the 1970s are an inexperienced workforce, unrest and poor labor-management relations, and slow adaptation to higher costs of complying with safety and environmental regulations. Ellerman, Stoker and Berndt (2001) study for U.S. coal mining productivity appearing in a National Bureau of Economic Research volume on productivity analysis develop a framework in which the productivity growth of a given aggregate can be decomposed into five effects: a scale effect; a fixed (industry-specific) effect; a price effect; a time effect; and a residual. The fixed effect is the most important driver of productivity. The authors aggregate their decomposed results in order to determine which of the price, fixed, time, scale and residual effects were most important in aggregate coal mining productivity in the United States for the 1972-1995 period. They find that by far the price effect was most important for the overall period and the 1972-1978 periods, but was slightly exceeded in importance by the fixed effect for the 1978-1995 periods, when coal prices were more or less on a steady decline.

Darmstadter (1999) is a non-technical but equally comprehensive analysis of coal mining productivity, which refers to the earlier study which Ellerman, Stoker and Berndt (2001), is based. Without attempting to rank their importance, he discusses six factors which have been important for U.S. coal mining productivity: shifts in production between different types of mines; adoption of new technologies; regulation; periods of labor unrest; improved management; and changing market environments, especially in the 1970s. Two important shifts have transpired in the production of coal in the past few decades in the US. The first is the shift from underground to surface operations, and the second from continuous to long wall techniques within underground production. Darmstadter (1999) gives a broad definition of technological progress, including improvements in the characteristics of new investments, increases in the scale of new investments, and increases in the skills base of the operators of such new investments. Flynn (2000) echoes several of the

\footnotetext{
${ }^{12}$ See Godwin ChukwudumNwaobi. "The Nigerian Coal Corporation: An Evaluation of Production Performance (1960-1987)" (PDF). Quantitative Economic Research Bureau.Retrieved 2008-04-12.

${ }^{13}$ See http://www.wise-uranium.org/upafr.htmlWISE Uranium Project. Retrieved 2013-07-29
} 
conclusions of Darmstadter (1999) and the earlier research that culminated in Ellerman, Stoker and Berndt (2001). He notes several advances in terms of mining equipment (i.e. scale and quality) and automated control, and also notes the favorable productivity impact of the shift to surface mining operations. The study also notes that existing firms are now facing difficulties in keeping up the pace of technological adoptions as continued price declines lead to lower profitability.

Further insight on the scale effect mentioned by Ellerman, Stoker and Berndt(2001) can be gained from Boyd (1987). In the discussion above of the more recent study, it was stated that the conclusion of higher productivity growth in larger mines could be driven either by increasing returns to scale or by the fact that larger firms are simply more capital intensive, but that it could not be determined which effect was present or dominating in that study. However, separate from this technology effect, Boyd (1987) is able to study the effects of capital intensity and returns to scale separately. The study uses a technically advanced production function to model firms with fixed effects (specifically, fixed geological properties, as is relevant to mines) and where returns to scale are dependent upon some of the inputs to production. His findings show that mines with higher investments in earth-moving machinery per worker tended to experience increasing returns to scale. Naples' (1998) study finds that labor-management relations are important and rather unnoticed factor in determining productivity performance in coal mining. In this sense, the study call more for policies dealing with improving labor relations rather than easing rules for merging coal mines, although the latter may play a role in the former. Research by Arsenault and Sharp (2008) in the Canada-based Centre for the Study of Living Standards (CSLS) found that mining MFP growth in Canada over the period 1973 to 2000 was negative $2.2 \%$. The findings suggest that Canada has experienced a more severe decline in MFP, negative $5.5 \%$ over the period 2000 to 2006. This is because the falling productivity of the sector is both the result of a rapid increase of its labor force and of the sudden increase in the exploitation of the oil sands.

Stylized Facts about Nigeria: In the Nigerian context, works on productivity studies such as Liedholm (1964), Osagie and Odaro (1975), Oaikhena (1997), Iyoha (2000), Ekanem and Oyefusi (2000), Ekanem (2000), Ajayi (2002), Jekelle (1987), Akinnusi (1987), Uruestone (1987), Adekoya (1987), Komolafe (1987 and, Usman (1987)on productivity and production functions have been going on for more than five decades. More so, the Buhari's Administration of 1983-1985 established the National Productivity Center to enhance productivity in governance. Due to the Minerals and Mining Act (2007) and the Minerals Regulations (2011), the Nigerian Geological Survey Agency has been strengthened to provide reliable geophysical and geological data and a Mining Cadastre Office has been established to regularize the sector's licensing procedures, and extensive mineral and mining promotions. The mining reform cycle normally has a long timeframe of over ten years to bring its full benefit to the economy and GDP. ${ }^{14}$ The Regional Program on Enterprise Development (RPED) (2001) survey discloses some remarkable results with regard to productivity. RPED interviewed over 200 firms in Nigeria's private sector. These firms are spread across nine sectors namely: chemical / pants, food / beverages, metal, non-metal, paper/ printing/publishing, pharmaceuticals, plastics, textiles, and wood. Value-added per worker (measured in US dollars) reveals the importance of labor in productivity. Value added per worker is driven by firm size and levels of workers morale. The smallest firms have the lowest value-added and the very large firms where workers are well treated have value added per worker considerably greater than other types of firms. Local firms have less than half the valued added of firms with foreign equity and firms owned by Black African entrepreneurs have a lower value-added than firms owned by reneurs of Indian, European, and Middle Eastern descent. Also, the result of the survey further showed that inputs of labor and capital are highly significant in determining value added per worker. The study also suggests that the ratio of skilled to unskilled workers is significant at 10 per cent level of confidence, as is capacity utilization and age of firm. But the magnitude of labor is the highest signifying that labor and improvement of labor is crucial to improving productivity (RPED, 2001 in Awe and Ayeni, 2013).

Dike (2005) explains workers morale as the mental and emotional condition as enthusiasm, confidence, or loyalty of individual or group with regard to the function or tasks at hand. He noted that humans are goal driven and once a goal is set, behavior aimed toward the goal persists until the goal is reached. But more

\footnotetext{
${ }^{14}$ See http://voiceofnigeria.org/Nigeria/Australia-and-Canada-to-support-Nigeria\%27s-mining-industry.html.
} 
often than not, a Nigerian worker works all his life without coming close to achieving his life goals. This sad situation is rampant today where an average worker cannot afford to meet his or her family's basic needs (food, clothing, water, decent shelter and healthcare according to Maslow, 1943). The lack of these basic needs have depressingly impacted their productivity.

It is unbelievable that despite the abundant material resources in Nigeria, the workers lack the necessary motivation to perform their jobs duties. Many workers are owed arrears of wages and salaries. The issue of resources mismanagement seems unsolvable in the society. And the issue of low productivity, which is caused by ineffective management, is common in the public sector. Strangely, many managers in the society lack the skills necessary to lead productive work force. Despite their poor performances, the managers of these inefficient institutions still get their salaries with the aid of subsidy. This is unthinkable in a serious society; good wage is normally tied to productivity (Dike, 2005). Akintade et al (2000) uphold that industrial disputes occurred as a result of non-realization of worker's aims and aspirations. Such disputes are then expressed in many ways such as strike actions, lock-out, go-slow, work-to-rule and overtime ban (Yesufu, 2000). The overtime ban is the refusal of Union members to work over time, in most cases this is meant to increase the production cost of the firm since the machine will be underutilized. The work-to-rule, on its own, is when workers follow the rule strictly to the extent that output is affected. This also serves to increase the production cost (Awe and Ayeni, 2013). The paper made an effort at discovering the determinants or causes of productivity growth in Nigeria. Attention was mainly centered on the last decade of the study period. In the pursuit of the study objective, the paper is organized into four sections. Section one presented the introduction. Section two reviews the literature, examines the stylized facts about Nigeria and theoretical framework of the study. In section three, the empirical model, methodology and empirical results are discussed. Section four concludes paper.

Theoretical Framework: Estimating production function is an exercise that involves determining the productivity of a particular sector or the entire economy. Productivity is a term used to describe the contribution of factor inputs in the production process. In some sense, it is often used synonymously with performance evaluation of those inputs, especially labor. Productivity is usually interpreted as an indicator of efficiency and productivity growth is usually viewed as the principal source of improvement in living standards. Production is the act of creating utility (Abiola, 2010). This means that production is not complete until the goods produced finally reach the consumers (Mansfield, 1985). A production function is a function that specifies the output of a firm, an industry, or an entire economy for all combinations of inputs (Wikipedia). It is the technical relationship between the inputs and the outputs. There are several ways of specifying the production function. In a general mathematical form, a production function can be expressed as:

$Q=f(X 1, X 2, X 3, \ldots, X n)$

where:

$Q=$ quantity of output

$X 1, X 2, X 3, \ldots, X n=$ factor inputs (such as capital, labor, land or raw materials).

This general form does not encompass joint production. That is, a production process, which has multiple coproducts or outputs. At the advanced stage of microeconomics, all the inputs in a typical production process are subsumed into two major inputs; the fixed inputs (often denoted by K) and the variable inputs (often denoted by L). So many types of production functions are obtainable in the theoretical literature. They include the two popular ones namely the Cobb-Douglas Production Function and Constant Elasticity of Substitution production function. Other less popular ones are the Quadratic production function and Transcendental Logarithmic production function. The Cobb-Douglas functional form of production functions is widely used to represent the relationship of an output to inputs. It was proposed by Knut Wicksell (18511926), and tested against statistical evidence by Charles Cobb and Paul Douglas in 1900-1928 as cited Abiola (2001). .A typical Cobb-Douglas production function is of the form:

$Q=A L^{\alpha} K^{\beta}$, 
where:

$Q=$ total production (the monetary value of all goods produced in year)

$L=$ labor input

$K=$ capital input

$A=$ total factor productivity or efficiency parameter.

$\alpha$ and $\beta$ are the output elasticities (substitution parameters) of labor and capital, respectively.

These values are constants determined by available technology. Output elasticity measures the responsiveness of output to a change in the levels of either labor or capital used in production, ceteris paribus. For example if $\alpha=0.15$, a $1 \%$ increase in labor would lead to approximately a $0.15 \%$ increase in output. Further, if: $\alpha+\beta=1$, the production function has constant returns to scale. That is, if $\mathrm{L}$ and $\mathrm{K}$ are each increased by $20 \%$, Y increases by $20 \%$. If $\alpha+\beta<1$, returns to scale are decreasing, and if $\alpha+\beta>1$ returns to scale are increasing.

\section{Methodology and Model Specification}

The choice of the econometric technique is borne out of the fact that the data used is time series data which is prone to autocorrelation. The causal relationship between the dependent variable of output and its determinants (capital and labor) was established, the issue of stationarity or otherwise of the data was discussed.

The Cobb-Douglas production function as applied in this study is:

$\mathrm{Q}=\mathrm{AK} \mathrm{K}^{\alpha} \mathrm{L}^{\beta}$

Equation 3 is not a convenient form for direct estimation by least squares methods; it is therefore usually converted into a logarithmic form:

$\log Q=\log A+\alpha \log K+\beta \log L+u$

So that the residual $\mathrm{u}$ is added in the multiplicative form eu.

A priori expectation suggests that both $\alpha$ and $\beta$ are greater than zero but less that one. That is

$0<\alpha<1$ and $0<\beta<1$. In the case where constant returns to scale is present, then $\alpha+\beta=1$. Alternatively, constant returns to scale may be imposed by putting $\beta=1-\alpha$

So that (3) can be rewritten as:

$\mathrm{Q}=\mathrm{AK}^{\alpha} \mathrm{L}^{1-\alpha} \mathrm{e}^{\mathrm{u}}=\mathrm{A}(\mathrm{K} / \mathrm{L})^{\alpha} \mathrm{Le}^{\mathrm{u}} \quad$ or $\quad \mathrm{Q} / \mathrm{L}=\mathrm{A}(\mathrm{K} / \mathrm{L})^{\alpha} \mathrm{e}^{\mathrm{u}}$

and taking logarithms of both sides gives

$\log \mathrm{Q} / \mathrm{L}=\log \mathrm{A}+\alpha \log (\mathrm{K} / \mathrm{L})+\mathrm{u}$

This second form avoids multicollinearity between $\log K$ and $\log L$ and also reduces heteroscedasticity if the variance of K is correlated with L (Wynn and Holden 1974)

The CES function is not easy to estimate directly like that of the Cobb-Douglas function. Estimation of the CES function has, therefore, generally been limited to either examining whether the condition for profit maximization are satisfied or making some approximation to the function. In this study, we make use of Kmenta (1967) approximation to CES cited in (Wynn and Holden, 1974). The approximation with the use of Taylor"s expansion series gives:

$\log (\mathrm{Q} / \mathrm{L})=\log \gamma+(\mathrm{v}-1) \log \mathrm{L}+\mathrm{v}(1-\delta) \log (\mathrm{K} / \mathrm{L})-0.5 v \delta \rho(1-\delta)[\log (\mathrm{K} / \mathrm{L}) 2]+\mathrm{u}$

The equivalent equation for the Cobb-Douglas function is as follows: 
$\log (\mathrm{Q} / \mathrm{L})=\log A+(\beta-1+\alpha) \log \mathrm{L}+\alpha \log (\mathrm{K} / \mathrm{L})+\mathrm{u}$

Thus, equations 6 and 7 form our structural equations and the result of the estimated equations are presented in the section that follows

\section{Data Analysis}

To avoid a spurious series, unit root test was conducted based on Augmented Dickey-Fuller (ADF) to test for the stationarity or otherwise of the variables in the model. The table below shows the result of the ADF conducted on all the variables. The test shows the variables are not stationary.

Table 2: Unit Root Test Results

\begin{tabular}{lll}
\hline Variables & $\begin{array}{l}\text { ADF } \\
\text { Statistic }\end{array}$ & Test \\
\cline { 2 - 3 } & Level & \\
\hline $\mathrm{Y}$ & -4.254941 & $\mathrm{I}(2)$ \\
$\mathrm{K}$ & -9.148372 & $\mathrm{I}(2)$ \\
$\mathrm{L}$ & -5.321441 & $\mathrm{I}(2)$ \\
& & \\
$1 \%$ Critical Value & -3.6661 & \\
$5 \%$ Critical Value & -2.9627 & \\
$10 \%$ Critical Value & -2.6200 &
\end{tabular}

Source: Author's Computation using E-Views 16.

Table 3: Ordinary Least Square Regression Result for C.E.S. Production Function

Dependent Variable: D(D(Y))

Method: Least Squares

Date: 07/30/13 Time: 17:36

Sample(adjusted): 19822011

Included observations: 30 after adjusting endpoints

\begin{tabular}{lllll}
\hline Variable & Coefficient & Std. Error & t-Statistic & Prob. \\
\hline $\mathrm{C}$ & 0.214828 & 0.222765 & 0.964369 & 0.3434 \\
$\mathrm{Ln}(\mathrm{K}))$ & 0.000121 & 0.001015 & 0.118868 & 0.9063 \\
$\mathrm{Ln}(\mathrm{L})$ ) & $1.48 \mathrm{E}-05$ & $2.75 \mathrm{E}-06$ & 5.375959 & 0.0000 \\
R-squared & 0.567475 & Mean dependent var & 0.220000 \\
Adjusted R-squared & 0.535436 & S.D. dependent var & 1.753499 \\
S.E. of regression & 1.195167 & Akaike info criterion & 3.289088 \\
Sum squared resid & 38.56743 & Schwarz criterion & 3.429207 \\
Log likelihood & -46.33632 & F-statistic & 17.71204 \\
Durbin-Watson stat & 2.617294 & Prob(F-statistic) & 0.000012 \\
\hline
\end{tabular}

Source: Own Computation.

Discussion of Result: The above result can be expressed in linear form based as follows:

$\operatorname{Ln}(\mathrm{Q} / \mathrm{L})=0.214828+1.48005 \operatorname{Ln}(\mathrm{L})+0.000121 \mathrm{Ln}(\mathrm{K} / \mathrm{L})$

The above equation shows a positive relationship between the output and the inputs which conforms to the a priori expectation of $0<\alpha<1$ and $0<\beta<1 . \alpha$ from the result is 0.000121 while $\beta$ is 1.48 (i.e. a unit change in labor will lead to change in output by $148 \%$ ), which confirms the existence of increasing returns to scale in the production function. The R-squared which is the explanatory power of the model is reasonably at $57 \%$. This means that $57 \%$ of the variations in output are explained by the inputs of labor and capital. This suggests that the remaining $43 \%$ are explained by other inputs such as innovations, technology, raw materials among 
others that are important in the production process. The Durbin-Watson of 2.62 suggests the absence of autocorrelation in the model. The F-statistic is equally good at 17.17, which implies that all the independent variables put together belong to the model.The result supports the studies of Douglas (1934) and Solow (1957) which established that labor is the only most significant factor of production. They also concluded that a one percent increase in labor seems to increase output about three times as much as would capital do. This study further established that other inputs such as innovations and technology are rightly important in the efficiency of production process. In fact, these inputs are momentous in view of the global economic dynamics. It is only improved capital that could propel the increase in these inputs.

\section{Conclusion and Recommendations}

This study examined productivity in the mining sector by way of estimating two major production functions known in the economics literature. The study made use of time series data between 1980 and 2011. The unit root test conducted confirms that the data are made stationary after conducting the second differencing to avoid spurious result at the end of the study. The result obtained from the OLS estimates shows that substitution parameters, $\alpha$ and $\beta$ support economic theory of the duo being positive values. The addition of the values of $\alpha$ and $\beta$ is greater than one which indicates that as the mining sector doubles its inputs in terms of labor and capital, the output will deepening. The study supports economic theory in the specification of the Cobb- Douglas function. It is also imperative to stress that other inputs such as innovations, technology, raw materials among others are important in the production process. Addition of these inputs in the mining process will further boost productivity especially with the global economic dynamics. The study established that the economic and market reforms undertaken under SAP which entailed deregulation of the foreign exchange system, trade policies, the financial system and agricultural policies have played a considerable role in enhancing productivity performance. The study concluded by advising that investment in mining sector needs be encouraged and increased to raise the overall rate of economic growth in the years ahead. It is therefore recommended that government should sustain the mining sector reforms and continue to place emphasis on institutional strengthening, transparency, accountability, and governance improvements in the sector. The political will of government and transparency to drive efficient reform process is required. The need for increased capital investment in innovations, technological process, technical manpower and instructions are key drivers of productivity growth over a long period of time.

\section{References}

Abiola, A. (2010). Capital-Labor Substitution and Banking Sector Performance in Nigeria (1960-2008). Central Bank of Nigeria. Economic and Financial Review, 48(2).

Adekoya, A. (1987). The Role of Government in Promoting Increased Productivity of Nigerian Farms. Proceedings of the First National Conference on Productivity, Published by National Productivity Centre, Abuja, Nigeria. Chapter, 7, 56-62.

Ajayi, S. T. (2002). Productivity Improvement and Incentive Schemes as Strategies for Productivity Improvement in Nigeria. Journal of Productivity, 1(1).

Akintade, I. R. \& Olu, P. A. (2000). Collective Bargaining - What you always wanted to know about Trade Union and never dared to ask, London, Macmillan.

Akinnusi, D. M. (1987). The Role of Technology in Productivity" Proceedings of the First National Conference on Productivity, Published by National Productivity Centre, Abuja, Nigeria. Chapter, 20, 214-226.

Arsenault, J. \& Sharpe, A. (2008). An Analysis of the Causes of Weak Labor Productivity Growth in Canada since 2000. International Productivity Monitor, 18, 14-39, Centre for the Study of Living Standards Ottawa, Canada.

Awe, A. A. \& Ayeni, R. K. (2013). Empirical Investigation into Industrial Relations and National Productivity in Nigeria. European Journal of Business and Management, 5(8).

Boyd, G. A. (1987). Factor Intensity and Site Geology as Determinants of Returns to Scale in Coal Mining. The Review of Economics and Statistics, 69(1), 18-23.

Bradshaw, M. J. (2005). Population, resources, development and the environment. In: Daniels, P. et al, eds. An Introduction to Human Geography: Issues for the 21st century. 2nd ed. (Section 2).

Bridge, G. (2008). Economic geography: natural resources. In: International Encyclopedia of Human Geography. Eds. Kitchin and Thrift. Elsevier. 
Brown, M. (1966). On the Theory and Measurement of Technological Change, Camb

Bituminous Coal Mining. (1955-1980). Eastern Economic Journal, 24(3), 325-342.

Chindo, M. (2011). An Extensive Analysis of Mining in Nigeria Using a GIS. Journal of Geography and Geology, 3(1), September, Available online at www.ccsenet.org/jgg on 02/09/14.

Davenport, J. (2010). Nigeria aiming to grow mining's GDP contribution to $15 \%$ by 2015 . Mining Weekly, March 15, 2010. Available online at: http://www.miningweekly.com/article/nigeria-to-growmining-sector -to-15-of-gdp-by-2015-2010-03-05 (April 20, 2010).

Darmstadter, J. (1999). Innovation and Productivity in U.S. Coal Mining, in R. David Simpsoned., Productivity in Natural Resource Industries: Improvement Through Innovation, (Washington, D.C.: Resources for the Future), p. 35-72.

Dike, V. (2005). Reward Systems, Worker Morale and Productivity. Africa Economic Analysis available on internet www.Africa Economic Analysis .org: Nigeria society at the dawn of the 21st century.

Douglas, P. H. (1934). Theory of Wages Macmillan New York.

Eggert, R. G. (2001). Mining and Economic Sustainability: National Economies and Local Communities. International Institute for Environment and Development supported by the World Business Council for Sustainable Development (WBCSD).

Ekanem, 0. T. (2002). Productivity in the Banking Industry in Nigerian Unpublished work.

Ekanem, 0. T. \& Oyefusi, S. A. (2000). Estimating Aggregate production Function for the Manufacturing Industry in Nigeria 1980-1997 Unpublished Work

Ellerman, D., Stoker, T. M. \& Berndt, E. R. (2001). Sources of Productivity Growth in the American Coal Industry 1972-95 in Charles R. Hulten, Edwin R. Dean and Michael J ed; New Developments in Productivity Analysis, National Bureau of Economic Research, pp. 373 - 418. University of Chicago Press

Girones, E. O., Pugachevsky, A. \& Walser, G. (2009). Mineral Rights Cadastre: Promoting Transparent Access to Mineral Resources. Extractive Industries for Development Series \#4 June 2009. Washington DC: The World Bank.

Gyang, J. D., Nanle, N. \& Chollom, S. G. (2010). An overview of mineral resources development in Nigeria: problems and prospects. Continental J. Sustainable Development, 1, 23-31

ICMM, the World Bank and UNCTAD Commodities Branch. (2007). Synthesis of four country case studies: the challenge of mineral wealth using resource endowments to foster sustainable development. London: ICMM.

Iyoha, M. A. (2000). The Sources of Economic Growth in Nigeria, 1960-1997: A Growth Accounting Exercise. Nigerian Economic and Financial Review, 5(2).

Jekelle, H. E. (1987). Employment Policies and Public Service Productivity A Paper presented at the Proceedings of the First National Conference on Productivity, Published by National Productivity Centre, Abuja, Nigeria. Chapter, 37, 412-423

Komolafe, K. (1987). Productivity in a Developing Economy" Proceedings of the First National Conference on Productivity, Published by National Productivity Centre, Abuja, Nigeria. Chapter, 3, 26-32

Krueger, A. O. \& Turner, B. (1982). growth of Factor productivity in Turkish Manufacturing Industries. Journal of Development Economics, 11, 307-325.

Liedholm, C. E. (1964). Production for Eastern Nigerian Industries. The Nigerian Journal of Economic and Social Studies, 24(1), 37-60.

Mansfield, E. (1985). Microeconomics- Theory and Application W.W. Norton \& Company, New York.

Maslow, A. H. (1943). A Theory of Human Motivation, New York, Harper and Row publishers.

Naples, M. I. (1998). Technical and Social Determinants of Productivity Growth in

Nwaobi, G. C. (2012). The Nigerian Coal Corporation: An Evaluation of Production Performance (1960-1987) (PDF). Quantitative Economic Research Bureau. Retrieved 2008-04-12

Oaikhena, H. E. (1997). Production Functions in the Nigerian Brewing Industry. The Nigerian Economic and Financial Review, 2(3).

Osagie, E. \& Odaro, L. (1975). Rate of Capital-Labor Substitution in Time Series Production Function in the Nigerian Manufacturing Industry 1960-1975. The Nigerian Journal of Economic and Social Studies, 24(1), 37-60.

Solow, R. M. (1957). Technical Change and the Aggregate Production Function. Review of Economics and Statistics, 39, 312-20. 
Uruestone, W. I. (1987). Productivity in a Developing Economy" Proceedings of the First National Conference on Productivity, Published by National Productivity Centre, Abuja, Nigeria. Chapter, 14, 143-159

Usman, G. A. (1987). Productivity Schemes and Implementation of Productivity Programmes" Proceedings of the First National Conference on Productivity, Published by National Productivity Centre, Abuja, Nigeria. Chapter, 25, 270-281.

Wynn, R. F. \& Holden, K. (1974). An Introduction to Applied Econometric Analysis, Macmillian Publication, New York

Yesufu, T. M. (2000). Trade Unions and Industrial Relations, Human Factor in National Development: Nigeria. Isted., Benin City, and Ibadan, University of Benin Press and Spectrum Books Limited. 